\title{
MATERIAL WRITING CHARACTERIZED NARRATION FOR ELEMENTARY SCHOOL
}

\author{
Darnis Arief ${ }^{a}$ \\ a Padang State University, Padang, Indonesia \\ Corresponding e-mail: nis.darnis@gmail.com
}

\begin{abstract}
Field observation of the authors shows that learning to write a narration in the fourth grade of elementary school has not been effective, so that the students' writing has not been in suitable with the provisions. Therefore, the development of teaching materials to write effective character narratives needs to be done. Research development consist of analysis, design of teaching materials, development of teaching materials, implementation, and evaluation that has been done. The designed teaching materials have been based on the results of the learning analysis. This research product in the form of teaching material of narrative writing character for grade IV of elementary school has been assessed by expert team, validated by learning expert and product user. In addition, at the implementation stage, has been done assessment of the process of student activity and assessment of student writing results. Based on the implementation and evaluation it was found that teaching materials to write character narratives have been developed with validity, effectiveness, and practicality in meeting educational standards. Thus, it is concluded that the instructional material design can be used effectively in order to improve the quality of narrative writing lesson for grade 4 students of Elementary School.
\end{abstract}

Keywords: Teaching Materials, Writting, Narration, Characters

\section{INTRODUCTION}

Language plays an important role in human life. It develops intellectual quotient, emotional quotient, and spiritual quotient. language is us as communication media so that people can express their ideal, interact each other, develop personality and pass the values of life.

Mastering Indonesian language passively and actively is very important for all of students in Indonesia. Indonesian language is used in all classroom in Indonesia as the main language. Students who face difficulties in Learning Indonesian language, will have difficulties in understanding other subjects. thus, Indonesian language is taught from elementary school levels. there are four language skills that should be learned by the students. the skills are speaking, reading, and writing. they are the important skills that play important roles in students' current and future life.

One of the goals of learning Indonesian in elementary school to develop students to communicate effectively and efficiently with the applicable ethics, both orally and in writing (Permen No. 22 of 2006). Students will be able to communicate effectively and efficiently in writing, for it is done in the elementary school learning writing in various forms, ranging from writing beginning to writing further.

Developing students' ability in writing is Beginning from lower classes (first and second grade) with the aim of introducing letter form, letter size, and how to write letters. Students are taught to be able to recognize letters and forms of letters. The study will be continued to write a letter. The phase is writing words and sentences. Writing a letter begins by writing a loose letter, after the advanced student is followed by writing the letter upright. The first and second grade of elementary students only learn basic skills of writing which is writing letter by letter. The next level of writing skill will be learned in higher levels. Another purpose of writing is to encourage students to express ideas and communicate information in writing. Further writing in KTSP's curricula (2006) consists of several basic competencies. basic competencies can be grouped into writing announcements, writing letters, writing reports, writing poetry, and writing essays. One basic competencies of writing that is learned by fourth grade students in elementary school is writing essay. Depdiknas (2008: 117) states that fourth grade students require to compose articles on a 
variety of simple topics by noticing the use of spelling (capital letters, periods, and commas)".

Writing skills is a productive skill that can only be obtained after a person is skilled at listening, speaking, and reading. This also causes writing skills to be the most difficult language skills. Although writing skills is difficult, but its role in human life is very important. Writing activities are needed in everyday human activities, such as writing notes, letters, reports, books, and articles. Writing is also important to make a report of discovery of science and technology.

Considering the importance of writing skill, it is necessary to be taught in the early age. However, students in elementary school have difficulties in writing lesson. based on interview with teachers in elementary school, it is revealed that writing becomes the most difficult skill to be mastered by students. The student has not been able to develop a given title into several paragraphs. When composing paragraphs, the paragraphs are often composed of several sentences. however, it is difficult to determine the idea of paragraphs.

Based on the observation that is conducted in 4th grade students of elementary school in Padang city, the class activity is begun by praying and check students' readiness to study. The subject is narration writing. students are asked about the definition of essay. The next activity is to attach a glowing image and be accountable. Based on the result of question and answer about the picture, determined by teacher title of writing.

After the title is determined, students are assigned to prepare the framework. Then the learning is continued by assigning the students to write the narrative to completion. Teachers helps students with several clues to help students in developing ideas. in the end of the class activity, teachers ask three or four students tp present their work in front of the class. to read their writing in front of the class in turn. The reads have not been revised and have not been disclosed.

This learning activities showed that, learning method that is used by teachers is a conventional method. Teachers do not provide students opportunity to choose what o write and develop their creativity in narration writing. Students are assigned to develop the framework, and then read the writing with emphasis on the writing. As a result, Students' narration writing skill is not developed as expected. Students have not been able to harmonize relationships. In addition, some of the sentences is not effective since there are several unnecessary words that are used. In terms of organizational composition, students have not been able to introduce the story, create conflict or solve the narrative well. This phenomenon is consistent with the findings of Suminto et al (2007) that students find difficulties to make the interesting beginning of a story, determine the ending, and work on conflict and climax. There are several errors in spelling and punctuation. Moreover, Suminto et al (2007) state that this condition is trigger by several factors. One of the factors is Teachers' limited in term of knowledge and time to develop lesson plan.

A workbook is a kind of book designed to guide students in carrying out tasks, questions, and exercises. Workbooks are a useful and useful educational tool. Workbooks are designed and organized based on the curriculum used in KTSP 2006. All tasks such as exercises, questions are carefully detailed and gradual. Teachers and students using the workbook are guided by clear instructions so that no misuse takes place.

The use of workbooks saves time. it is because the instructions are clearly arranged; the language is tailored to the students' use of the workbook; the question is arranged systematically. Moreover, it can be expected a quick and precise response from the students. When this happens the time in learning is used effectively. This means time is used effectively and efficiently. 


\section{METHOD}

The method used in this research is quasi experiment. This method is used to investigate the possibility of causal interconnection is a group consisting of thirty students subject to the treatment of learning to write a narration using a workbook. Furthermore, comparing the results with the control group consisted of thirty students subjected to conventional treatment conditions.

The population of this research is the fourth grade students of elementary in SDN 21 Bandar Buat Padang which consists of four classes. Determination of the research samples were using random sampling because the four classes proved to be homogeneous. Research data is collected from the result of students' essay. The instrument that is used to obtain the data is essay assessment guidelines. The instrument were prepared by reviewing the Indonesian Language Research Unit (GBPP) KTSP 2006 writing aspect. The assessment guidelines are assessed and validated by an Indonesian language learning expert. Data were analyzed by t-test and Wilcoxon test. Experiment Implementation

1. Experimental Classroom Learning Procedure

The research is done in two meetings. In the first meeting, the learning is begun by praying, students' readiness, conveying the purpose of learning, and question and answer about the activity of writing. The teacher explains that the student will be composed a narrative essay which is guided by the workbook. Next use the workbook students write the narrative in accordance with the stages of writing. Using student workbooks to observe pictures, read, discuss, and do exercises. Activities at the first meeting, among others, determine the topic, frame, and discuss the learning materials to write narrative. The second meeting, after the apperception of students writing narrative, revise, edit, and publish his writing.

2. Control group learning Procedures

Learning to write a narrative is a one-time meeting. teachers, tells the students to pray, and takes the students' readiness. Teacher asked questions about the essay. Furthermore, the teacher showed series of images. Students were asked to arrange the framework. The following activities are students writing narratives. The completed essay is read in front of the class

\section{RESULT AND DISCUSSION}

\section{1 Research Results}

3.1.1 Post-test results

\subsubsection{Experiment Group Result}

The data obtained from narrative writing skills consists of ideas, sentences, spelling and punctuation. Each component with range one to five. Thus, the lowest total score is three (3) and the highest score is 15 . The highest score obtained by experiment group 13, and the lowest 7 with an average of 10.82 and standard deviation 1.57.

\subsubsection{Control group results}

The post-test control group score ranged from 6 to 12 . The mean score was 8.58 with standard deviation of 1.46 .

\subsubsection{Pretest results}

\subsubsection{Experiment Group Results}

The highest score of pretest experimental group was 11 , the lowest score was 5 , with an average of 7.79. Standard deviation 1.75

\subsubsection{Control Group Results}

The highest score obtained by the control group 11 , the lowest score 5 with an average of 7.84 standard deviation 1.70

\subsubsection{Testing Requirements Analysis}

Determining the statistics that will be used in Means difference means test required pre-analysis. the analysis are Normality and homogeneity tests.the result of normality and homogeneity of pre-test will be described as follows:

\subsubsection{Normality Test of Pre-test of}

Experiment Group

The average score of experiment group is 7.79 with standard deviation 1.75 and chi-squared 5.11 with a significant level of 0.05 . It means that.

\subsubsection{Testing Control Group Normality}

The average score of the control group was 7.84 with standard deviation $1.7,5.51$ square chi. While chi squared table with $\mathrm{dk}=(\mathrm{k}-1)$ is 6 significant level of $0.05=12,592$. It turns out that $\mathrm{X} 2$ counts small from the table, thereby concluding the data is normal.

\subsubsection{Pretest Homogeneity Test}

The calculation results are $\mathrm{S} 1=3.0621$ and S2 2 $=2,1438, \mathrm{n} 139, \mathrm{n} 238 . \mathrm{F}$ arithmetic $1.43, \mathrm{~F}$ table with a significant level of 0.05 is 1.74 . Thus, $F$ calculates a small of $\mathrm{F}$ table. It can be concluded that the data is homogenous.

\subsubsection{Analysis of the Pretes Data Tests}

The average pretest grade of the experimental group score was 7.79 with the standard deviation of 1.75. The average pretest grade control score was 7.84 with standard deviation 1.70

$\mathrm{T}$ arithmetic obtained -0.96 . After consultation with $\mathrm{t}$ table with $\mathrm{dk}(\mathrm{n} 1+\mathrm{n} 2-2)$ significant level 0.05 , obtained t table 1.67 . Compared $t$ count with $t$ 
table was $\mathrm{t}$ big table from $\mathrm{t}$ arithmetic. Thus, it can be concluded that the initial skill of the experimental class did not differ significantly with the initial skills of the control class.

\subsubsection{Normality Test of Post-test Data of Experiment Class}

The average post-test class score of experiments was 10.82, standard deviation 1.57 and chi square 9.09. In consultation with chi squared table with $\mathrm{dk}(\mathrm{k}-1)$ 6, 0.05 significance level was obtained chi square table 12,592, then it can be concluded normal data distribution.

\subsubsection{Testing Normality of Post-test Control}

class

Data processing of control grade postes was obtained on average 8.58 , standard deviation of 1.46 and chi square of 6.63 , chi square of table with $\mathrm{dk} 6$ and significance level of 0.05 was 12,592. it is concluded data distribution is normal.

\subsubsection{Homogeneity test of Post-test}

The result of post-test data calculation obtained variance one (S1 2) 2,467, variance two (S2 2) 2,6828 n1 39, n2 38. F arithmetic 0,92 F table with significant level 0,05 is 1,74 . Thus the data varied homogeneously.

\subsubsection{Hypothesis Testing}

Hypothesis testing is done by parametric analysis in this case t-test. t-test is used because data processing shows normal distributed data and homogeneous variation.

\subsubsection{Testing the Minor Hypothesis} Class

1) Normality Test "Ideas aspects" of Experiment

Idea aspect scores ranged from 2 to 5 , the average of 3.59 with standard deviation 3.64 , x 2 counting 119.40, x 2 table 9.49, the data is not normally distributed.

2) Normality test of Sentences aspect

Scores obtained ranged from 2-5, averaging 3.59 standard deviations of 3.98 . After the calculation obtained $\mathrm{x} 2$ count larger than $\mathrm{x} 2$ tables, it is concluded the data is not normally distributed.

3) Normality test of Spelling and Punctuation

For "spelling and punctuation", the score ranges from 2-5, averaging 3.64 with standard deviation 3.69. Performed calculations obtained $\mathrm{x} 2$ count larger than $\mathrm{x} 2$ table, it is concluded that data is not normally distributed.

Data processing aspects of ideas, sentences, spelling and punctuation indicate that the distribution of data is not normal, then the next hypothesis testing using Wilcoxon Test.

\subsubsection{Wilcoxon Test}

\subsubsection{Wilcoxon Test Aspect Ideas}

The experiment class and control class scores range from 2-5. Differences scores of both classes 12. The Wilcoxon test is obtained $\mathrm{J}$ arithmetic 205 ,
A table for $95 \%$ confidence level is 89 . The criteria for acceptance of the hypothesis are (a) If $J$ counts large of $\mathrm{J}$ tables then there is no significant effect, (b) If $\mathrm{J}$ Count small or equal to $\mathrm{J}$ table then there is significant influence.

Based on these criteria, it is concluded that there is no meaningful influence on the use of workbooks against the ideas / ideas of students in writing narrative.

\subsubsection{Wilcoxon Test Aspect of sentences}

The difference between the experimental class score and the control class is 30 . From Wilcoxon test obtained $\mathrm{J}$ count $78, \mathrm{~J}$ table 89 , it is concluded that there is a significant influence from the use of workbook to the students' writing in narrative writing.

\subsubsection{Wilcoxon Test Aspect of Spelling and Punctuation}

Differences of experimental class score with control class is 46. From Wilcoxon test obtained J count $19, \mathrm{~J}$ table 89 , it is concluded that there is significant influence from the use of workbook to use jaan and punctuation in writing narration.

\subsection{Discussion Of Research Results}

The results showed that students who taught to write narratives using a workbook more skilled than students who taught with conventional method. This means that the workbook has proved effective in learning narrative writing for the fourth grade of elementary school. Workbooks helpstudents to improve their narrative writing skills. Students can assemble events in chronological order. The notion that the students are raising begins to be organized systematically. In addition, students have been able to use capital letters early in the sentence and at the beginning of the person's name. Students already use the dot at the end of a sentence. Sentences that are produced are effective.

Students enthusiastically learn, read, observe, discuss, and do the exercises. The workbook used by students creates excitement and motivation in writing. Students are seen actively observing, reading, asking, and writing.

The improvement due to the effectiveness of workbook to encourage students in writing a narrative essay, developing ideas and self learning. They get information through reading. If the information is difficult to be understood, they can discuss with friends or with teachers. In addition, the workbook guides students to do writing exercises with clear, easy-to-understand instructions. Workbooks compiled using interesting pictures and colors motivate students to learn to write narratives.

The story idea used in student writing is personal experience. This finding is consistent with Karim's research findings (2007), among others "characteristic of short story students' ideas derived 
from personal experiences / friends and revolves around the world of children". Some student writings do not contain conflict, either self-conflict or social conflict with other characters. This finding is in line with Karim's research findings (2007).

\section{CONCLUSIONS}

\subsection{Conclusion}

The use of workbooks in narrative writing lessons influences the students' narrative writing skills. Students' writing results are better than those written by students who do not use textbooks.

4.2 Suggestions

It is recommended to grade IV elementary school teachers using workbook in narrative writing lesson.

\section{REFERENCES}

[1] Badan Standar Nasional Pendidikan. 2006. Kurikulum Tingkat Satuan Pendidikan Jenjang Pendidikan Sekolah Dasar. Jakarta: Departemen Pendidikan Nasional.

[2] Cox, Carole. 1999. Teaching Language Arts. California State University: Long Beach.

[3] Emzir. 2011. Metodologi Penelitian Pendidikan Kuantitatif \& Kualitatif. Jakarta: PT Raja Grafindo Persada.

[4] Karim Kodrat Hi. 2007. Implementasi Pendekatan Proses untuk Meningkatkan Keterampilan Menulis Narasi Siswa Kelas V SD Inpres I Tanah Tinggi Ternate. (Online). Diakses 20 Pebruari 2011.

[5] Nana Syaodih Sukmadinata. 2008. Metode Penelitian Pendidikan. Bandung: PT Remaja Rosdakarya.

[6] Suminto A Sayuti dkk. 2007. Pengembangan Model Pembinaan Menulis Karya Sastra bagi Anak dan Remaja. (Online), diakses 10 Februari 2011.

[7] Sugiyono. 2011. Metode Penelitian Pendidikan Pendekatan Kuantitatif, Kualitatif, dan $R$ \& D.Bandung: Alfabeta.

[8] Tompkins, Gail E. 1994. Teaching Writing Balancing Proces and Product. State niversity, Los Angeles: Fresno. 